\title{
UPAYA MENINGKATKAN HASIL BELAJAR PKn MENGGUNAKAN MODEL ACTIVE LEARNING TIPE ROLE REVERSAL QUESTION PADA SISWA KELAS V DI SD NEGERI 060898 MEDAN
}

\author{
Derliana Siregar \\ Surel: derlianasiregar@gmail.com
}

\begin{abstract}
ABSTRAK
Penelitian ini bertujuan untuk mendeskripsikan peningkatan hasil belajar PKn dengan menggunakan model active learning tipe role reversal question pada siswa kelas V SD N 060898 Kecamatan Medan Maimun. Jenis penelitian ini merupakan penelitian tindakan kelas. Subjek penelitian adalah siswa kelas V SD N 060898 Kecamatan Medan Maimun berjumlah 36 siswa. Adapun indikator keberhasilan tindakan ditandai dengan $\geq 75 \%$ dari jumlah siswa yang mengikuti proses pembelajaran telah memperoleh nilai $\geq 70$. Hasil penelitian menunjukkan adanya peningkatan hasil belajar PKn siswa kelas V SD N 060898 Kecamatan Medan Maimun setelah menggunakan model active learning tipe role reversal question baik pada siklus I maupun siklus II.
\end{abstract}

Kata Kunci: Hasil Belajar, Pkn, Active Learning

\section{PENDAHULUAN}

Pendidikan diselenggarakan dengan memberdayakan semua komponen masyarakat melalui peran serta dalam penyelenggaraan dan pengendalian mutu layanan pendidikan. Menurut Undang-Undang Nomor 20 Tahun 2003 pendidikan mempunyai andil yang penting dalam menentukan proses pencapaian tujuan pendidikan nasional yaitu mengembangkan potensi peserta didik agar menjadi manusia yang beriman dan bertaqwa kepada Tuhan Yang Maha Esa, berakhlak mulia, sehat, berilmu, cakap, kreatif, mandiri dan menjadi warga negara yang demokratis serta bertanggung jawab. terdapat beberapa siswa yang membuat gaduh. Guru berulangkali mengkondisikan siswa yang gaduh untuk diam dan memperhatikan pembelajaran, namun hal tersebut tidak dihiraukan. Selain membuat gaduh saat pembelajaran PKn, terdapat beberapa siswa yang tidak mengerjakan tugas dengan sungguhsungguh. Ketika selesai menjelaskan pembelajaran guru memberikan tugas kepada siswa untuk mengerjakan soal, namun banyak siswa yang mengerjakannya dengan asal-asalan, karena mereka tidak mau membaca buku untuk menjawab soal. Keadaan tersebut menimbulkan pemerolehan hasil belajar yang belum masimal. Rendahnya hasil belajar Pkn dapat dilihat dari data nilai semester I tahun ajaran 2013/2014. Rata-rata nilai PKn 
lebih rendah dibandingkan nilai Bahasa Indonesia dan IPS. Diketahui bahwa nilai rata-rata Bahasa Indonesia 74, IPS 68, dan PKn 66. Selain nilai rata-rata $\mathrm{PKn}$ rendah diperoleh data bahwa baru 18 siswa atau $50 \%$ dari jumlah siswa yang belum memenuhi KKM yang ditentukan yaitu 65. Melihat jumlah siswa yang masih banyak memperoleh nilai dibawah kriteria ketuntasan dan rata-rata nilai $\mathrm{PKn}$ yang belum maksimal maka perlu dilakukan peningkatan hasil belajar PKn.

Model pembelajaran merupakan pedoman dan segala sesuatu yang dibutuhkan dalam kegiatan pembelajaran baik berupa sumber, bahan atau alat yang akan digunakan. Hal ini sesuai dengan pendapat Joyce dan Weil (Hamruni, 2011: 5) model pembelajaran adalah suatu perencanaan yang digunakan sebagai pedoman dalam merencanakan pembelajaran di kelas dan untuk menentukan perangkatperangkat pembelajaran termasuk di dalamnya buku-buku, film, komputer, kurikulum, dan lain-lain.

Model pembelajaran yang dapat diterapkan di kelas yaitu model active learning atau model pembelajaran aktif. Active learning atau pembelajaran aktif merupakan model pembelajaran yang mengacu pada tujuan pembelajaran, melibatkan siswa, menggunakan seni, gerakan dan panca indera serta langkah dan kegiatan dalam pembelajaran (Hollingsworth, Pat \& Gina Lewis, 2008: 8-9). Sedangkan menurut Naswatul Lailah (2003:25) pembelajaran aktif merupakan proses pembelajaran yang menitik beratkan pada aktifitas siswa baik yang bersifat fisik, mental, emosi maupun intelektual untuk mencapai tujuan pendidikan yang berhubungan dengan aspek kognitif, afektif dan psikomotorik. Dari pengertian tersebut dapat diketahui bahwa active learning merupakan kegiatan belajar yang mengaktifkan siswa, dalam artian siswa terlibat langsung dalam pembelajaran yang berhubungan dengan aspek kognitif, afektif dan psikomotorik. Berdasarkan penjelasan di atas dapat diketahui keunggulan model pembelajaran aktif (Active Learning) yaitu siswa turut aktif dalam kegiatan pembelajaran, siswa menggunakan segala potensi yang dimiliki dalam proses belajar. Penggunaan model pembelajaran aktif (Active Learning) menjadikan pembelajaran berpusat kepada siswa bukan berpusat pada guru. Keunggulan lain dari pembelajaran aktif (Active Learning) yaitu dapat memupuk sikap siswa untuk dapat berfikir kritis tentang materi yang dipelajari.

Menurut Silberman, Mel (2007:143) ada berbagai tipe Active Learning yang menekankan pada 
kegiatan tanya jawab yaitu starts with a question, role reversal question dan planted question. Kegiatan tanya jawab dapat membantu siswa untuk memperoleh

pengetahuan, keterampilan dan keaktifan dalam belajar. Hal tersebut sesuai dengan penelitian yang dilakukan oleh Agus Karoni (2011) bahwa active learning starts with a question dalam pembelajaran PKn dapat meningkatkan aktivitas bertanya siswa.

Dalam penelitian ini juga digunakan active learning yang menekankan pada kegiatan tanya jawab, namun terdapat perbedaan yaitu menggunakan role reversal question. Penerapan role reversal question yaitu dengan melakukan tanya jawab dengan bertukar peran. Dengan melakukan tanya jawab dapat memudahkan siswa untuk memahami materi, menjadikan siswa aktif, dan dapat meningkatkan hasil belajar. Seperti yang sudah dipaparkan sebelumnya kegiatan guru dalam menyampaikan pembelajaran PKndi kelas V SD N 060898 Kecamatan Medan Maimun. Berdasarkan uraian di atas, peneliti terdorong untuk mengadakan penelitian dengan judul "Upaya Meningkatkan Hasil Belajar PKn Menggunakan Model Active Learning Tipe Role Reversal Question Pada Siswa Kelas V SD N 060898 Kecamatan Medan Maimun”.
Berdasarkan latar belakang yang telah dikemukakan di atas dapat diidentifikasi masalah sebagai berikut:

1. Kegiatan pembelajaran monoton, guru selalu menggunakan metode ceramah.

2. Siswa kurang aktif dalam pembelajaran, ditandai dengan kegiatan pembelajaran didominasi oleh guru.

3. Motivasi siswa dalam mengikuti pembelajaran rendah, terlihat saat mengikuti proses pembelajaran siswa membuat gaduh dan tidak mengerjakan tugas dengan sungguhsungguh.

4. Nilai rata-rata $P K n$ masih rendah, untuk itu perlu dilakukan peningkatan hasil belajar.

5. Guru belum menerapkan model active learning tipe role reversal question dalam kegiatan pembelajaran PKn.

Berdasarkan identifikasi masalah di atas, peneliti membatasi masalah pada upaya meningkatkan hasil belajar PKn menggunakan Model Active Learning Tipe Role Reversal Question pada siswa kelas V SD N 060898 Kecamatan Medan Maimun.

Berdasarkan batasan masalah di atas, maka rumusan masalah dalam penelitian ini adalah bagaimana meningkatkan hasil belajar PKn dengan menggunakan Model Active Learning Tipe Role Reversal 
Question pada siswa kelas V SD N 060898 Kecamatan Medan Maimun?

Berdasarkan rumusan masalah di atas, maka tujuan penelitian ini adalah untuk mendeskripsikan peningkatan hasil belajar PKn siswa kelas V SD N 060898 Kecamatan Medan Maimun dengan menggunakan Model Active Learning Tipe Role Reversal Question.

Penelitian ini diharapkan dapat memberikan manfaat. Adapun manfaat penelitian ini adalah:

1. Manfaat Teoritis

Hasil penelitian ini diharapkan dapat memberikan masukan dalam melakukan kegiatan pembelajaran di kelas, khususnya yang berhubungan langsung dengan peningkatan hasil belajar PKn di Sekolah Dasar dengan menerapkan model active learning tipe role reversal question.

2. Manfaat Praktis

\section{a. Bagi Siswa}

Penelitian ini dapat menjadikan siswa aktif dalam pembelajaran PKn sehingga terjadi peningkatan hasil belajar.

b. Bagi Guru

Guru dapat menerapkan model active learning tipe role reversal question dalam mata pelajaran PKn untuk meningkatan hasil belajar siswa.

\section{METODE PENELITIAN}

Penelitian ini merupakan penelitian tindakan kelas (classroom action research). Menurut Suharsimi Arikunto, dkk (2007:3) penelitian tindakan kelas merupakan suatu pencermatan dari kegiatan pembelajaran berupa tindakan yang sengaja dimunculkan dan terjadi pada sebuah kelas secara bersama. Adapun tujuan penelitian ini adalah untuk meningkatkan hasil belajar PKn menggunakan model Active Learning tipe Role Reversal Question kelas V SDN Medan Maimun.

Subyek penelitian ini adalah siswa-siswi kelas V SD N 060898 Kecamatan Medan Maimun yaitu sebanyak 36 siswa. Terdiri dari 21 siswa laki-laki dan 15 siswa perempuan. Sedangkan obyek penelitian ini adalah hasil belajar PKn menggunakan model active learning tipe role reversal question.

Ada beberapa ahli yang mengemukakan model penelitian tindakan, namun secara garis besar terdapat empat tahapan yang dilalui yaitu (1) perencanaan, pelaksanaan, (3) pengamatan dan (4) refleksi.

Metode pengumpulan data yang digunakan dalam penelitian tindakan kelas ini meliputi tes, observasi, dan dokumentasi. Adapun metode pengumpulan data dilakukan sebagai berikut.

1. Tes

Dalam penelitian ini tes digunakan ialah tes tertulis dengan bentuk objektif (pilihan ganda). 
Tujuan penggunaan tes dalam penelitian ini untuk mengukur hasil belajar PKn siswa kelas V SD N 060898 Kecamatan Medan Maimun, yaitu dengan mengerjakan soal evaluasi pembelajaran yang telah ditentukan oleh peneliti.

\section{Observasi}

Dalam penelitian ini jenis observasi yang dilakukan menggunakan observasi sistematis sehingga membutuhkan instrument dalam pengamatan yang sudah dirancang sebelumnya. Kegiatan observasi yang dilakukan pada penelitian ini untuk mengatahui kondisi pembelajaran $\mathrm{PKn}$ yang berlangsung di kelas V SD N 060898 Kecamatan Medan Maimun. Pengamatan dilakukan selama pelaksanaan tindakan untuk mengamati penerapan model active learning tipe role reversal question.

\section{Dokumentasi}

Menurut Sugiyono (2009: 129) dokumentasi adalah catatan peristiwa yang sudah berlalu, bisa berbentuk tulisan, gambar atau karya menumental. Dalam penelitian ini digunakan dokumen untuk mendukung serta melengkapi data-data penelitian. Data yang digunakan berupa lembar observasi guru dan siswa daftar nilai serta RPP yang digunakan dalam penerapan model active learning tipe role reversal question.

Dalam penelitian tindakan kelas (PTK) analisis data diarahkan untuk mencari dan menemukan upaya yang dilakukan guru dalam meningkatkan hasil belajar siswa terutama pada mata pelajaran PKn dengan menggunakan model Active Learning Tipe Role Reversal Question. Dengan demikian analisis data yang digunakan dalam penelitian kelas dapat menggunakan analisis kuantitatif.

Untuk menghitung persentase hasil belajar dan aktivitas siswa menggunakan rumus sebagai berikut.

$$
\text { Persentase }(\%)=\frac{\text { Jumlah skor yang diperoleh }}{\text { Jumlah skor maksimal }} \times 100 \%
$$

Perhitungan hasil dan aktivitas belajar siswa ditafsirkan dalam kriteria sebagai berikut (Endang Poerwanti dkk, 2008:6-18)

\section{HASIL DAN PEMBAHASAN}

Penelitian tindakan kelas ini dilaksanakan di SD Negeri 060898 Kecamatan Medan Maimun. Kegiatan pembelajaran dimulai pukul 07.0012.10 WIB sedangkan untuk hari jumat dimulai dari pukul 07.00-10.40 WIB. Suasana di daerah sekitar SD N 060898 Kecamatan Medan Maimun, berada di daerah pemikiman warga namun keadaannya tetap asri dan 
kondusif untuk kegiatan pembelajaran.

Berdasarkan hasil observasi dan pra-tindakan yang telah dilakukan terhadap proses pembelajaran PKn, maka disusunlah rencana perbaikan terhadap proses pembelajaran dengan menggunakan model active learning tipe role reversal question sehingga diharapkan dapat meningkatkan hasil belajar PKn pada siswa kelas V SD N 060898 Kecamatan Medan Maimun.

Pada siklus I terjadi peningkatan rata-rata hasil belajar sebesar $8,75 \%$ yaitu dari 66,53 pada kondisi awal menjadi 75,27. Jumlah siswa yang memperoleh nilai $\geq 70$ mengalami peningkatan sebesar $25 \%$ dari kondisi awal $44 \%$ menjadi $69 \%$. Hal ini membuktikan bahwa tindakan pada siklus I memiliki pengaruh terhadap hasil belajar siswa pada mata 1 . pelajaran PKn.

Peningkatan hasil belajar siswa pada siklus I disebabkan oleh model active learning tipe role reversal question yang diterapkan oleh guru. Model active learning tipe role reversal question menekankan pada aktivitas tanya jawab dengan bertukar peran (Silberman Mel, 2007: 149).

Dalam penelitian ini masih terdapat keterbatasan peneliti. Keterbatasan tersebut yaitu penerapan model active learning tipe role reversal question dalam pelaksanaan pembelajaran PKn dilakukan secara sederhana belum menggabungkan model Active Learning tipe lain.

\section{SIMPULAN}

Berdasarkan hasil penelitian dan pembahasan dapat disimpulkan bahwa pembelajaran PKn mengunakan model active learning tipe role reversal question dapat meningkatkan hasil belajar siswa kelas V SD N Minomartani 6 Sleman. Hal ini ditunjukkan dengan siswa yang memperoleh nilai $\geq 70$ pada siklus I meningkat sebesar $25 \%$ dari kondisi awal $44 \%$ menjadi $69 \%$. Kemudian siswa yang memperoleh nilai $\geq 70$ pada siklus II mengalami peningkatan $28 \%$ menjadi $97 \%$. Nilai rata-rata pada siklus I mengalami peningkatan sebesar $8,75 \%$

1. dari kondisi awal 66,53 menjadi 75,28 pada siklus I kemudian pada siklus II nilai ratarata mengalami peningkatan lagi sebesar 10,97\% menjadi 86,25. Adapun saran dalam penelitian ini adalah:

1. Bagi siswa Siswa hendaknya lebih berani dalam mengemukakan pendapat, pertanyaan dan ide yang dimiliki tidak hanya dalam pelajaran PKn saja namun pada mata pelajaran yang lain selalu baik.

2. Bagi Guru diharapkan dapat menggunakan model active learning tipe role reversal question dalam meningkatkan hasil belajar siswa pada mata pelajaran lain. Selain itu guru diharapkan dapat 
mengembangkan model Active Learning Tipe Role Reversal Question untuk menunjang kegiatan pembelajaran, sehingga dapat mengoptimalkan potensi yang dimiliki siswa dalam memperoleh ilmu.

\section{DAFTAR RUJUKAN}

Agus Karoni. 2011. Pembelajaran Active Learning Starts With a Question untuk meningkatkan keaktifan bertanya siswa dalam pembelajaran PKn kelas IV MIM Sraten, Sukoharjo Tahun Ajaran 2010/2011. Skripsi. UIN Sunan Kalijaga Yogyakarta.

Agus Suprijono. 2009. Cooperative Learning: Teori dan Aplikasi PAIKEM. Yogyakarta: Pustaka Pelajar.

A.Ubaedillah \& Abdul Rozak. 2013. Pendidikan

Kewarganegaraan (Civic Education): $\quad$ Pancasila, demokrasi, hak asasi manusia dan masyarakat madani. Jakarta: ICCE UIN Syarif Hidayatullah.

Ari Samandhi. 2009. Pembelajaran Aktif (Active Learning). Jakarta: Teaching Improvement Worshop Enginering Education Development Project.

Baharudin dan Esa Nur Wahyuni. 2009. Teori Belajar dan
Pembelajaran. Yogyakarta: Ar-Ruzz Media.

Desmita. 2009. Psikologi Perekembangan Peserta Didik: Panduan Bagi Orang Tua Dan Guru Dalam Memahami Psikologi Anak Usia SD, SMP, SMA. Bandung: PT. Remaja Rosdakarya.

Diana Mutiah. 2010. Psikologi Bermain Anak Usia Dini. Jakarta: Kencana Prenada.

Endang Poerwanti dkk. 2008. Asesmen Pembelajaran SD. Jakarta: Dirjen Dikti.

Hamruni. 2011. Strategi Pembelajaran. Yogyakarta: Insan Madani.

Hamzah B. Uno dan Nurdin Mohamad. 2012. Belajar dengan Pendekatan PAILKEM: Pembelajaran Aktif, Inovatif, Lingkungan, Kreatif, Efektif, Menarik. Jakarta: PT.Bumi Aksara.

Hiszyam Zaini. 2008. Strategi Pembelajaran Aktif. Yogyakarta: Insan Madani.

Hollingsworth, Pat \& Gina Lewis. 2008. Pembelajaran Aktif: Meningkatkan Keasyikan Kegiatan Di Kelas. Penerjemah: Dwi Wulandari. Jakarta: Indeks. 
Sri Esti Wuryani Djiwandono. 2002.

Psikologi Pendidikan. Jakarta:

Grasindo Garamedia

Widiasarana Indonesia.

Sugihartono, dkk. 2007. Psikologi Pendidikan. Yogyakarta: UNY Press.

Suharsimi Arikunto. 2007. Penelitian Tindakan Kelas. Jakarta: Bumi Aksara.

Suyono dan Hariyanto. 2011. Belajar dan Pembelajaran. Bandung: PT. Remaja Rosdakarya. 